\title{
Chemical composition of volatile extract from Inula aschersoniana Janka var. aschersoniana growing in Bulgaria
}

\author{
Milka Todorova $^{1}$, Antoaneta Trendafilova ${ }^{1, *}$, And Dimitar Dimitrov ${ }^{2}$ \\ ${ }^{1}$ Institute of Organic Chemistry with Centre of Phytochemistry, Bulgarian Academy of Sciences, Acad. G. Bonchev Str., Bl. 9, 1113 Sofia, Bulgaria \\ ${ }^{2}$ National Museum of Natural History, Bulgarian Academy of Sciences, 1 Tzar Osvoboditel Blvd., 1000 Sofia, Bulgaria \\ *Corresponding author: trendaf@orgchm.bas.bg
}

Received: September 28, 2017

Accepted: November 4, 2017

Published on-line: November 7, 2017

Published: December 25, 2017

\begin{abstract}
The chemical composition of the volatile oil of Inula aschersoniana was studied by GC and GC-MS. Forty-five constituents representing $\mathbf{9 2 . 9 \%}$ of the total oil were detected. The oil contained fatty acids $(55.2 \%)$ and alkanes (14.1\%), followed by oxygenated monoterpenes $(9.6 \%)$, sesquiterpenoids $(7.1 \%)$ and aromatic compounds $(4.5 \%)$. It is characterized by relatively low content of terpenoids in total $16.7 \%$ only of which linalool $(2.1 \%)$ and $\tau$-cadinol $(2.2 \%)$ were the dominant components in this class of compounds. Cluster analysis (CA) was used for determination of the relationship between the species in Inula verbascifolia aggregate.
\end{abstract}

Key words: aschersoniana; volatile components; GC; GC-MS; CA

http://dx.doi.org/10.5937/leksir1737021T

\section{INTRODUCTION}

The genus Inula (Asteraceae) consists of 100 species, some of which are known as plants used in traditional medicine. A literature survey revealed that Inula plants are rich source of biologically active compounds, mainly sesquiterpene lactones, flavonoids, and triterpenoids (Seca et al., 2014; 2015). Surprisingly, the information on essential oil composition of Inula species is scarce and only few biological activities have been reported - antibacterial (Deriu et al., 2008; Priydarshi et al., 2016), antifungal (Chauhan and Saxena, 1985; Haoui et al., 2016), and influence of I. helenium essential oil on electroencephalographic activity of the human brain (Sowndhararajan et al., 2016). Inula aschersoniana Janka is a species with areas of distribution in Bulgaria, Greece, Macedonia, and Turkey (The Global Species, 2009). Three varieties of I. aschersoniana - var. madarense, var. macedonica and var. aschersoniana are identified in Bulgaria (Delipavlov et al., 2003; Stojanov et al., 1967). Our previous phytochemical investigation of I. aschersoniana Janka var. aschersoniana afforded parthenolide, diepoxycostunolide, inusoniolide, chrysosplenol $C$ and four pseudoguaiane derivatives (Trendafilova et al., 2014). The essential oil composition of $I$. aschersoniana has not been studied yet. In continuation of our phytochemical work on Inula essential oils, herein we report the chemical composition of the volatile fraction of $I$. aschersoniana var. aschersoniana growing in Bulgaria.

\section{MATERIALS AND METHODS}

1. Plant material

Flowers of $I$. aschersoniana were collected in July 2015 near Marziganiza hut $\left(41^{\circ} 53^{\prime} 32.8^{\prime \prime} \mathrm{N} 24^{\circ} 52^{\prime} 47.8^{\prime \prime} \mathrm{E}\right)$ in Rhodope Mts, Bulgaria. A voucher specimen (SOM169980) has been deposited in the Herbarium of the Institute of Biodiversity and Ecosystem Research, Sofia, Bulgaria.

\section{Preparation of the essential oil}

Air-dried flowers were subjected to a micro hydrodistillationextraction in a Likens-Nickerson apparatus for 3 hours using diethyl ether as a solvent. The essential oil dissolved in diethyl ether was dried over anhydrous $\mathrm{Na}_{2} \mathrm{SO}_{4}$. After filtration, the solvent was removed under $\mathrm{N}_{2}$ flow, and the essential oil was stored at $4^{\circ} \mathrm{C}$ before analysis. The oil yield was $0.6 \mathrm{mg} / \mathrm{g}$.

3. Gas chromatography (GC) and Gas chromatography mass spectrometry (GC-MS)

The GC analysis was performed with a Shimadzu 17A gas chromatograph equipped with FID and an HP5-MS fusedsilica capillary column ((5\%-phenyl)-methylpolysiloxane, 30 $\mathrm{m} \times 25 \mathrm{~mm}$ i.d., film thickness $0.25 \mu \mathrm{m})$. The column temperature was programmed from $50^{\circ} \mathrm{C}\left(4 \mathrm{~min}\right.$ isotherm), to $240^{\circ} \mathrm{C}$ at a rate of $4^{\circ} \mathrm{C} / \mathrm{min}$, to $300^{\circ} \mathrm{C}$ at a rate of $10^{\circ} \mathrm{C} / \mathrm{min}$, and held at this temperature for $10 \mathrm{~min}$, the injector and detector temperatures were $260^{\circ} \mathrm{C}$, carrier gas - $\mathrm{N}_{2}$ (linear velocity, 33 $\mathrm{cm} / \mathrm{s}$ ), split ratio, 1:100. Relative percentage amounts were calculated from peak area without the use of correction factors. 
GC-MS analysis was performed on a HP 6890 Plus instrument with MS detector 5973 of the same company. Mass detector was operated in electron ionization mode $(70 \mathrm{eV})$ at a mass range of 30-450 Da. All chromatographic conditions and the column were as described above (for GC Analysis) except for the carrier gas, which was He. Retention indices (RI) of the oil components were calculated by using retention times of $\mathrm{C}_{8}-\mathrm{C}_{30}$ n-alkanes under the same chromatographic conditions according to Van den Dool's method (van Den Dool and Dec. Kratz, 1963). The individual components were identified by their RI, referring to known compounds from the literature (Adams, 2009; Tkachev, 2008) and by comparison of their mass spectra with those of NIST 98, WILEY and homemade MS databases.

\section{Statistical analysis}

The single linkage clustering method based on linkage distances was used to determine similarities between the examined samples (Statistica 10.0 package)

\section{RESULTS AND DISCUSSION}

Hydrodistillation of I. aschersoniana flowers gave pale yellow oil, which was further analyzed by GC and GC-MS. Forty-five volatile constituents in concentration more than $0.1 \%$, representing $92.9 \%$ of the total oil were listed in Table 1 . Forty-three compounds were identified, and the chemical type of two components was determined. The oil was primarily composed of fatty acids $(55.2 \%)$ and alkanes $(14.1 \%)$, smaller amounts of oxygenated monoterpenes $(9.6 \%)$, sesquiterpenoids $(7.1 \%)$ and aromatic compounds (4.5\%). It should be noted the abundance of fatty acids, of which octanoic, dodecanoic, and decanoic acids were principal constituents of the oil (16.8, 13.7 and $9.3 \%$, respectively). The aliphatic hydrocarbons pentacosane $(5.4 \%)$, heptacosane $(3.5 \%)$ and nonacosane $(2.5 \%)$ also presented in the oil in significant concentrations.

The oil is characterized by relatively low content of terpenoids in total $16.7 \%$ only. Linalool $(2.1 \%)$ and $\tau$-cadinol $(2.2 \%)$ were the dominant components in this class of compounds. Megastigmatrienone- 2 and megastigmatrienone- 4 were detected now for the first time in Inula species. Megastigmatrienones are dinor-isoprenoids derived from carotenoids and have been found mainly in members of the Solanaceae (D'Abrosca et al., 2004; Osorio, 2003) but also have been identified in Lamiaceae (Stachys palustris) (Senatore et al., 2007) and Asteraceae (Bidens pilosa) (Deba et al., 2008) essential oils.

The literature review showed that the rare essential oil component $\beta$-damascenone accounted for $0.2 \%$ in the studied oil is not unusual for the genus Inula. It has been detected in volatile extracts of $I$. verbascifolia ssp. parnassica(Tzakou et al., 2001) , I. cappa (Priydarshi et al., 2016), I. crithmoides (Tsoukatou and Roussis, 1999), and I. viscosa (Madani et al., 2014). Methyl jasmonate, detected in remarkable concentration of $1.0 \%$ in the studied oil is a compound isolated from Jasmine flowers (Adams, 2009). It has been previously found also in oils from species of Asteraceae family, like Artemisia absinthium (Ueda and Kato, 1980), A. kermanensis Ganjali and Pourramezani Harati (2012), A. aucheri (Badrabadi et al., 2015), Rhaponticum acaule (Boussaada et al., 2008), etc., but it was detected now for the first time in Inula species. I. aschersoniana Janka (syn. I. verbascifolia subsp. aschersoniana Janka) belongs to $I$. verbascifolia aggregate that includes also I. verbascifolia (Willd.) Hausskn., I. fragilis Boiss. \& Hausskn., I. heterolepis Boiss. (syn. I. verbascifolia subsp. heterolepis (Boiss.) Tutin), I. methanaea Hausskn. (syn. I. verbascifolia subsp. methanaea (Hausskn.) Tutin) and I. parnasica Boiss. \& Heldr. (I. verbascifolia subsp. parnassica (Boiss. \& Heldr.) Tutin) (Euro+Med, 2006). The literature survey revealed that only the volatile fractions from I. verbascifolia (Iv) of Croatian origin (Fontana
Table 1. Percentage composition of Inula ashersoniana essential oil

\begin{tabular}{|c|c|c|}
\hline $\mathbf{R I}^{\mathrm{a}}$ & Compounds & $\%$ \\
\hline 965 & hexanoic acid & 6.0 \\
\hline 1069 & cis-linalool oxide & 0.7 \\
\hline 1085 & trans-linalool oxide & 0.7 \\
\hline 1093 & linalool & 2.1 \\
\hline 1108 & phenylethyl alcohol & 0.2 \\
\hline 1135 & $\mathrm{C}_{10} \mathrm{H}_{18} \mathrm{O}^{\mathrm{b}}$ & 1.1 \\
\hline 1168 & octanoic acid & 16.8 \\
\hline 1189 & $\alpha$-terpineol & 1.4 \\
\hline 1226 & nerol & 1.8 \\
\hline 1251 & geraniol & 1.8 \\
\hline 1268 & nonanoic acid & 0.5 \\
\hline 1365 & decanoic acid & 9.3 \\
\hline 1384 & $\beta$-damascenone & 0.2 \\
\hline 1411 & methyl eugenol & 0.2 \\
\hline 1455 & allo-aromadendrene & 0.8 \\
\hline 1511 & tridecanal & 0.5 \\
\hline 1515 & $\gamma$-cadinene & 0.3 \\
\hline 1564 & dodecanoic acid & 13.7 \\
\hline 1567 & cis-3-hexenyl benzoate & 0.7 \\
\hline 1580 & megastigmatrienone-2 & 0.5 \\
\hline 1585 & caryophyllene oxide & 0.8 \\
\hline 1626 & megastigmatrienone-4 & 0.3 \\
\hline 1644 & $\tau$-cadinol & 2.2 \\
\hline 1650 & methyl jasmonate & 1.0 \\
\hline 1660 & $\alpha$-cadinol & 1.2 \\
\hline 1700 & $(Z, Z)$-farnesol & 0.3 \\
\hline 1750 & $\mathrm{C}_{15} \mathrm{H}_{24} \mathrm{O}^{\mathrm{c}}$ & 0.3 \\
\hline 1757 & benzyl benzoate & 1.7 \\
\hline 1762 & tetradecanoic acid & 2.7 \\
\hline 1845 & 6,10,14-trimethyl-2-pentadecanone & 0.9 \\
\hline 1858 & 2-phenylethyl benzoate & 0.2 \\
\hline 1863 & pentadecanoic acid & 0.8 \\
\hline 1865 & benzyl salicylate & 1.5 \\
\hline 1916 & $(E, E)$-farnesyl acetone & 0.2 \\
\hline 1960 & hexadecanoic acid & 4.5 \\
\hline 2140 & (Z,Z)-9,12-octadecadienoic acid & 0.8 \\
\hline 2146 & cis-9-octadecenoic acid & 0.1 \\
\hline 2300 & tricosane & 1.0 \\
\hline 2400 & tetracosane & 0.4 \\
\hline 2500 & pentacosane & 5.4 \\
\hline 2600 & hexacosane & 0.5 \\
\hline 2700 & heptacosane & 3.5 \\
\hline 2800 & octacosane & 0.5 \\
\hline 2900 & nonacosane & 2.5 \\
\hline \multirow[t]{2}{*}{3100} & hentriacontane & 0.3 \\
\hline & Total & 92.9 \\
\hline
\end{tabular}

a Retention indices to $\mathrm{C}_{8}-\mathrm{C}_{30}$ n-alkanes on HP-5MS column

$\mathrm{b}_{m / z}$ (rel. int.): $154\left(4,\left[\mathrm{M}^{+}\right), 139(4), 136(1), 126(42), 111\right.$ (30), 95(8), 81 (20), $67(100), 39(32)$

${ }^{c} m / z$ (rel. int.): $220\left(36,[M]^{+}\right), 205$ (38), 202 (16). 187 (20), 177 (17), 159 (42), 145 (38), 133 (40), 121 (43), 105 (62), 93 (84), 79 (68), 67 (69), 55 (76), 41 (100). 
et al., 2014), I. verbascifolia subsp. methanaea (Ivm) and I. verbascifolia subsp. parnassica (Ivp) both from Greece (Tzakou et al., 2001) have been studied so far. Comparison of the results for Bulgarian I. ashersoniana (Ia) essential oil with those published for Iv (Fontana et al., 2014), Ivp and Ivm (Tzakou et al., 2001) showed a big variety in their chemical composition (Fig. 1). Thus, high concentrations of alkanes (18.8\% and $14.1 \%)$ and

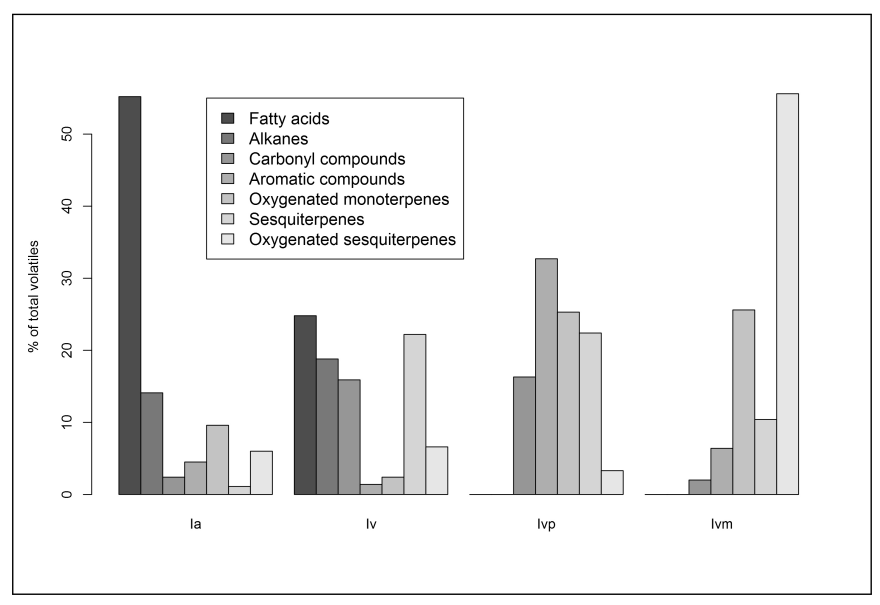

Fig. 1. Comparison of the main classes of compounds found in $I$. aschersoniana (Ia) and other related species I. verbascifolia (Iv), I. verbascifolia subsp. methanaea (Ivm) and I. verbascifolia subsp. parnassica (Ivp) published in the literature (Tzakou et al., 2001; Fontana et al., 2014)

fatty acids (22.8\% and $55.2 \%)$ are characteristic features for Iv and Ia. These classes of constituents are not present in Ivm and Ivp. On the other hand, Croatian sample (Iv) was rich in sesquiterpene hydrocarbons $(22.2 \%)$ and carbonyl compounds (15.9\%) like Ivp (22.4\% and $16.3 \%$, respectively), while these types of compounds in Ia were $1.1 \%$ and $2.4 \%$, respectively. In addition, Ivp contained relatively high amounts of aromatic compounds (32.7\%) and oxygenated monoterpenes $(25.3 \%)$. cis-Chrysanthenol (17.3\%), caryophyllene (13.2\%) and methyl salicylate $(23.4 \%)$ were the most abundant constituents in Ivp. Further, Ivm mis distinguished from the others as its oil was mainly consisting of terpenoids (91.6\%). Linalool (21.2\%) was the principal component among oxygenated monoterpenoids $(25.6 \%)$, while $\tau$-cadinol $(19.5 \%)$ and (Z)-nuciferol (16.6\%) dominated in the sequiterpene group $(55.6 \%)$. It should be noted, that the lack of monoterpene hydrocarbons was a common feature for these four species. The observed differentiation of the samples was further supported by cluster analysis (Fig. 2), which showed three distinct groups based on the Euclidian distance. The first group (Iv and Ia) was characterized by high content of alkanes and fatty acids. The second cluster (Ivp) contained almost equal amounts of oxygenated monoterpenes, sesquiterpene hydrocarbons and aromatic compounds. The third cluster (Ivm) contained primarly terpenoids $(91.6 \%)$.

\section{CONCLUSION}

In conlucion, the volatile components discussed above showed significant variety in chemical composition of the studied up to now species from I. verbascifolia aggregate. Further investigation of oil composition of I. fragilis Boiss. \& Hausskn., I. heterolepis Boiss. (syn. I. verbascifolia subsp. heterolepis) as well as I. aschersoniana var. madarense and I. aschersoniana var. macedonica will complete the information on the relationship between the species in this aggregate.

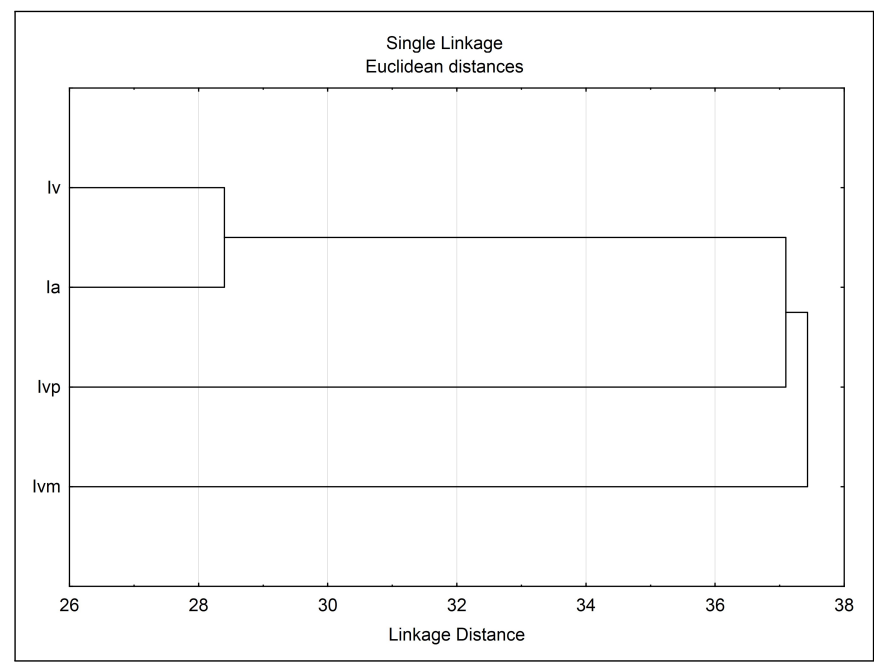

Fig. 2. Dendrogram performed from essential oils components of $I$. aschersoniana (Ia) and other related species I. verbascifolia (Iv), I. verbascifolia subsp. methanaea (Ivm) and I. verbascifolia subsp. parnassica (Ivp) published in the literature (Tzakou et al., 2001; Fontana et al., 2014)

\section{ACKNOWLEDGMENTS}

Acknowledgment. The authors are thankful to the National Science Fund, Ministry of Education and Science, Bulgaria, for financial support of Project DH09/11.

\section{REFERENCES}

Adams, R. P. (2009). Identification of Essential Oil Components by Gas Chromatography/mass Spectorscopy, 4th edn, Allured Business Media, Carol Stream, Illinois, USA.

Badrabadi, A., Kachouei, M. A., Pirbalouti, A. G. and Hamedi, B. (2015). Chemical Compositions of Essential Oil of Artemisia aucheri Collected from the Alpine Regions in Kerman, Iran, Journal of Essential Oil Bearing Plants 18(3): 596604.

Boussaada, O., Ammar, S., Saidana, D., Chriaa, J., Chraif, I., Daami, M., Helal, A. and Mighri, Z. (2008). Chemical composition and antimicrobial activity of volatile components from capitula and aerial parts of Rhaponticum acaule DC growing wild in Tunisia, Microbiological Research 163(1): 8795.

Chauhan, P. and Saxena, V. (1985). Antifungal activity of essential oil of leaves of inula cuspidata, Indian Journal of Pharmaceutical Sciences 47: 160-161.

D'Abrosca, B., DellaGreca, M., Fiorentino, A., Monaco, P., Oriano, P. and Temussi, F. (2004). Structure elucidation and phytotoxicity of C13 nor-isoprenoids from Cestrum parqui, Phytochemistry 65(4): 497-505.

Deba, F., Xuan, T. D., Yasuda, M. and Tawata, S. (2008). Chemical composition and antioxidant, antibacterial and antifungal activities of the essential oils from Bidens pilosa Linn. var. Radiata, Food Control 19(4): 346-352.

Delipavlov, D., Ceschmedziev, I., Popova, M., Terzijski, D. and Kovachev, I. (2003). Key to the Plants in Bulgaria, University of Agriculture, Plovdiv. (in Bulgarian).

Deriu, A., Zanetti, S., Sechi, L. A., Marongiu, B., Piras, A., Porcedda, S. and Tuveri, E. (2008). Antimicrobial activity of Inula helenium L. essential oil against Gram-positive and Gram-negative bacteria and Candida spp., International Journal of Antimicrobial Agents 31(6): 588-590. 
Euro+Med (2006). The Euro+Med PlantBase - the information resource for Euro-Mediterranean plant diversity. URL: http://ww2.bgbm.org/EuroPlusMed/query.asp

Fontana, G., Bruno, M., Senatore, F. and Formisano, C. (2014). Volatile constituents of aerial parts of two Mediterranean species of Inula : Inula crithmoides L. and I. verbascifolia (Willd.) Hausskn. (Asteraceae), Natural Product Research 28(13): 984-993.

Ganjali, A. and Pourramezani Harati, M. (2012). Chemical composition and antimicrobial of essential oil of Artemisia kermanensis, International Conference on Bioscience, Biochemistry and Bioinformatics IPCBEE, Vol. 31, pp. 28-31.

Haoui, I. E., Derriche, R., Madani, L. and Oukali, Z. (2016) Extraction of Essential Oil from Inula viscosa (L.) Leaves: Composition, Antifungal Activity and Kinetic Data, Journal of Essential Oil Bearing Plants 19(1): 108-118.

Madani, L., Derriche, R. and Haoui, I. E. (2014). Essential oil of Algerian Inula viscosa leaves, Journal of Essential Oil Bearing Plants 17(1): 164-168.

Osorio, C. (2003). Studies on aroma generation in lulo (Solanum quitoense): enzymatic hydrolysis of glycosides from leaves, Food Chemistry 81(3): 333-340.

Priydarshi, R., Melkani, A. B., Mohan, L. and Pant, C. C. (2016) Terpenoid composition and antibacterial activity of the essential oil from Inula cappa (Buch-Ham. ex. D. Don) DC, Journal of Essential Oil Research 28(2): 172-176.

Seca, A. M., Grigore, A., Pinto, D. C. and Silva, A. M. (2014) The genus Inula and their metabolites: From ethnopharmacological to medicinal uses, Journal of Ethnopharmacology 154(2): 286-310

Seca, A. M. L., Pinto, D. C. G. A. and Silva, A. M. S. (2015) Metabolomic Profile of the Genus Inula, Chemistry E Biodiversity 12(6): 859-906.

Senatore, F., Formisano, C., Rigano, D., Piozzi, F. and Rosselli, S. (2007). Chemical Composition of the Essential Oil from Aerial Parts of Stachys palustris L. (Lamiaceae) Growing Wild in Southern Italy, Croatica Chemica Acta 80(1): 135-139.

Sowndhararajan, K., Cho, H., Yu, B., Song, J. and Kim, S. (2016). Effect of inhalation of essential oil from Inula helenium L. root on electroencephalographic (EEG) activity of the human brain, European Journal of Integrative Medicine 8(4): 453-457.

Stojanov, N., Stefanov, B. and B., K. (1967). Flora of Bulgaria, Vol. 2, Nauka i Izkustvo, Sofia.

The Global Species (2009). Accessed 1-nov-2017. URL: $h t t p: / / w w w . g l o b a l s p e c i e s . o r g / n t a x a / 2286300$

Tkachev, A. (2008). Issledovanie letuchikh veshchestv rastenii (Study of Volatile Substances of Plants), Novosibirsk.

Trendafilova, A., Todorova, M., Genova, V., Shestakova, P., Dimitrov, D., Jadranine, M. and Milosavljevic, S. (2014) New pseudoguaiane derivatives from Inula aschersoniana Janka var. aschersoniana., Natural product communications 9(8): 1123-1124.

Tsoukatou, M. and Roussis, V. (1999). Chemical Composition and Intra Mediterranean Variation of the Inula crithmoides L. Oil, Journal of Essential Oil Research 11(2): 199-202.
Tzakou, O., Petropoulou, A., Harvala, C. and Constantinidis, T. (2001). Volatile Compounds of Two Members of Inula verbascifolia group: I. verbascifolia (Willd.) Hausskn. ssp. Parnassica (Boiss. Et Heldr.) Tutin and I. verbascifolia ssp. Methanea (Hausskn.) Tutin, Journal of Essential Oil Research 13(5): 364-366.

Ueda, J. and Kato, J. (1980). Isolation and Identification of a Senescence-promoting Substance from Wormwood (Artemisia absinthium L.), Plant physiology 66(2): 246-249.

van Den Dool, H. and Dec. Kratz, P. (1963). A generalization of the retention index system including linear temperature programmed gas-liquid partition chromatography, Journal of Chromatography A 11: 463-471. 